\title{
JUAL-BELI TANAH HAK MILIK YANG BERTANDA BUKTI PETUK PAJAK BUMI (KUTIPAN LETTER C)
}

\author{
Urip Santoso \\ Fakultas Hukum Universitas Airlangga Surabaya \\ e-mail: urip_sts@yahoo.com
}

\begin{abstract}
ABSTRAK
Hak Milik atas tanah dapat dialihkan melalui jual-beli. Dengan jual-beli, hak milik atas tanah berpindah dari pemilik tanah sebagai penjual kepada pihak lain sebagai pembeli. Jual-beli hak milik atas tanah dapat didaftarkan apabila memenuhi syarat materiil dan syarat formal. Syarat materiil berkaitan dengan kewenangan dan hak dari pihak penjual dan pembeli, sedangkan syarat formal berkaitan dengan pembuktian jual-beli hak milik atas tanah. Pendaftaran jual-beli tanah ke Kantor Pertanahan Kabupaten atau Kota harus mensyaratkan adanya jual-beli yang dibuktikan dengan adanya Akta Pejabat Pembuat Akta Tanah, tidak cukup dengan Akta di bawah tangan. Kata Kunci: jual-beli, tanah hak milik, syarat materiil, syarat formal.

ABSTRACT

Property rights of land could be transferred through trading activities, this activity could transfer owner (seller) land proprietary to the buyer. This land proprietary trading activity could be registered if it meets the material and formal requirements. The material requirements are related to the rights and authority of the seller and buyer, while the formal requirements are related to the evidence of the land proprietary trading activity. It is presupposed by the regency or city land office to do the proprietary land trading activity which must be proven by the official land officer deed (Pejabat Pembuat Akta Tanah) for the purpose of the land proprietary trading activity registration. Non official deed (not done before a notary) will not be approved.
\end{abstract}

Keywords: trading, land proprietary, material and formal requirements.

\section{PENDAHULUAN}

Dalam Undang-Undang No. 5 Tahun 1960 tentang Peraturan Dasar Pokok-pokok Agraria atau yang lebih dikenal pula dengan sebutan Undang-Undang Pokok Agraria (yang selanjutnya disebut UUPA), dalam Pasal 4 ayat 1 ditetapkan bahwa atas dasar hak menguasai dari negara sebagai yang dimaksud dalam Pasal 2, ditentukan adanya macam-macam hak atas permukaan bumi yang disebut tanah. Tanah tersebut dapat diberikan kepada dan dipunyai oleh orangorang, baik sendiri maupun bersama-sama dengan orang lain serta badan-badan hukum.

Berdasarkan hak menguasai, negara mempunyai suatu wewenang menentukan macam-macam hak atas tanah yang dapat diberikan kepada dan dipunyai oleh orang-orang dari warga negara Indonesia (yang selanjutnya disebut WNI) maupun orang-orang asing yang berkedudukan di Indonesia, baik sendiri-sendiri maupun bersama-sama dengan orang lain, juga kepada badan hukum privat dan hukum publik, atau badan hukum yang didirikan menurut hukum Indonesia dan berkedudukan di Indonesia dan badan hukum asing yang mempunyai perwakilan di Indonesia.

Hak atas tanah ialah hak yang memberi wewenang kepada pemegang haknya untuk mempergunakan dan atau mengambil manfaat dari tanah yang dihaki. Kata mempergunakan mengandung pengertian bahwa hak atas tanah untuk kepentingan mendirikan bangunan, sedangkan kata mengambil manfaat mengandung pengertian bahwa hak atas tanah untuk kepentingan pertanian, perikanan, peternakan, dan perkebunan. Maria S.W. Sumardjono menyatakan bahwa hak atas tanah sebagai suatu hubungan hukum didefinisikan sebagai hak atas permukaan bumi yang memberi wewenang kepada pemegangnya untuk menggunakan tanah yang bersangkutan beserta tubuh bumi, dan air, serta ruang yang ada di atasnya (Maria S.W. Sumardjono, 2008:128).

Hak-hak atas tanah yang ditentukan oleh negara, macamnya dapat dijabarkan dalam Pasal 16 ayat 1 UUPA dan Pasal 53 UUPA. Pasal 16 ayat 1 UUPA 
menetapkan bahwa hak-hak atas tanah sebagai yang dimaksud dalam Pasal 4 ayat 1 antara lain: Hak Milik; Hak Guna Usaha; Hak Guna Bangunan; Hak Pakai; Hak Sewa untuk Bangunan; Hak Membuka Tanah; Hak Memungut Hasil Hutan; dan Hak-hak lain yang tidak termasuk dalam hak-hak tersebut di atas yang akan ditetapkan dalam dengan undang-undang, serta hak-hak yang sifatnya sementara sebagaimana yang disebutkan dalam Pasal 53.

Dari macam-macam hak atas tanah yang telah disebutkan dalam Pasal 16 ayat 1 UUPA dan Pasal 53 ayat 1 UUPA dikelompokkan menjadi 3 (tiga) bidang, yaitu: Pertama, Hak atas tanah yang bersifat tetap. Hak atas tanah yang bersifat tetap adalah hak atas tanah yang akan tetap ada sepanjang UUPA masih berlaku atau belum diganti dengan undang-undang yang baru. Macam hak atas tanah ini adalah Hak Milik, Hak Guna Usaha, Hak Guna Bangunan, Hak Pakai, Hak Sewa untuk Bangunan, Hak Membuka Tanah, dan Hak Memungut Hasil Hutan; Kedua, Hak atas tanah yang akan ditetapkan dengan undangundang. Hak atas tanah yang akan ditetapkan dengan undang-undang adalah hak atas tanah baru yang akan ditetapkan dengan undang-undang. Macam hak atas tanah ini belum ada; dan Ketiga, Hak atas tanah yang bersifat sementara. Hak atas tanah yang bersifat sementara adalah hak atas tanah yang berlaku untuk sementara waktu, dalam waktu yang singkat akan dihapuskan karena mengandung sifat-sifat pemerasan.

Salah satu hak atas tanah yang ditetapkan dalam UUPA adalah Hak Milik. Hak milik disebutkan dalam Pasal 16 ayat 1 huruf a, Pasal 20 sampai dengan Pasal 27, Pasal 50 ayat 1, dan Pasal 56 UUPA. Ketentuanketentuan tentang hak milik yang diatur dalam UUPA adalah bersifat pokok-pokoknya saja atau secara garis-garis besar saja, sehingga masih membutuhkan pengaturan lebih lanjut. Ketentuan Pasal 50 ayat 1 UUPA menetapkan bahwa ketentuan-ketentuan lebih lanjut mengenai hak milik di atur dengan undangundang. Sampai sekarang undang-undang tentang hak milik yang diperintahkan oleh Pasal 50 ayat 1 UUPA belum terbentuk. Oleh karena undang-undang tentang hak milik belum terbentuk, maka yang berlaku adalah ketentuan-ketentuan hukum adat setempat dan peraturan-peraturan lain mengenai hak atas tanah yang tidak bertentangan dengan jiwa dan ketentuan UUPA, hal ini ditegaskan dalam Pasal 56 UUPA.

Hak milik termasuk salah satu hak atas tanah yang bersifat primer, yaitu hak atas tanah yang dapat dimiliki atau dikuasai secara langsung oleh seseorang atau badan hukum yang mempunyai waktu lama dan dapat dipindahtangankan kepada orang lain atau ahli warisnya (Supriadi, 2007:64). Hak atas tanah yang bersifat primer adalah hak atas tanah yang berasal dari Tanah Negara.

Pengertian hak milik disebutkan dalam Pasal 20 ayat 1 UUPA adalah hak turun-temurun, terkuat, dan terpenuh yang dapat dipunyai orang atas tanah dengan mengingat ketentuan dalam Pasal 6 UUPA. Turun-temurun artinya hak milik atas tanah dapat berlangsung terus selama pemiliknya masih hidup dan bila pemiliknya meninggal dunia, maka hak miliknya dapat dilanjutkan oleh seorang ahli warisnya sepanjang memenuhi syarat sebagai subyek hak milik. Terkuat, artinya hak milik atas tanah lebih kuat bila dibandingkan dengan hak atas tanah yang lain, tidak mempunyai batas atau jangka waktu tertentu, mudah dipertahankan dari gangguan pihak lain, dan tidak mudah hapus. Terpenuh, artinya hak milik atas tanah memberi wewenang kepada pemiliknya paling luas bila dibandingkan dengan hak atas tanah yang lain, dapat menjadi induk bagi hak atas tanah yang lain, dan penggunaan tanahnya lebih luas bila dibandingkan dengan hak atas tanah yang lain. Hak milik hanya dapat dipunyai oleh orang yang berkewarganegaraan Indonesia tunggal, bank-bank pemerintah, badan keagamaan, dan badan sosial.

Dilihat dari segi pembuktiannya, ada hak milik atas tanah yang sudah didaftarkan oleh pemiliknya ke Kantor Pertanahan Kabupaten atau Kota, sehingga diterbitkan sertifikat sebagai tanda bukti haknya. Ada pula hak milik atas tanah yang belum didaftarkan oleh pemiliknya ke Kantor Pertanahan Kabupaten atau Kota, sehingga belum diterbitkan sertipikat sebagai tanda bukti haknya. Hak milik atas tanah ini sebelum berlakunya UUPA tanggal 24 September 1960 dikenal dengan nama hak agrarisch eigendom, milik, yasan, andarbeni, hak atas druwe, hak atas druwe desa, pesini, grant sultan, landerijenbezitrecht, altijdurende erfpacht, dan hak usaha atas bekas tanah partikelir. Hak milik atas tanah ini ada yang diterbitkan tanda bukti berupa Petuk Pajak Bumi atau Landrente, Girik, Pipil, Kekitir, Verponding Indonesia. Sekarang ini, tanda bukti tersebut diganti menjadi Kutipan Letter C, diterbitkan oleh Kepala Desa atau Kepala Kelurahan.

Hak milik atas tanah menurut Pasal 20 ayat 2 UUPA dapat beralih dan dialihkan kepada pihak lain. Salah satu contoh perbuatan hukum yang berbentuk dialihkan adalah jual-beli, artinya hak milik atas tanah dapat diperjualbelikan oleh pemiliknya kepada pihak lain. Permasalahan yang hendak dikaji dan dirumuskan yaitu apa syarat sah jual-beli tanah hak milik yang bertanda bukti Petuk Pajak Bumi (Kutipan Letter C). 


\section{PEMBAHASAN}

Syarat Sah Jual-Beli Tanah Hak Milik yang Bertanda Bukti Hak Petuk Pajak Bumi (Kutipan Letter C)

UUPA menetapkan bahwa Hak Milik, Hak Guna Usaha, dan Hak Guna Bangunan dapat beralih dan dialihkan kepada pihak lain. Demikian juga, Peraturan Pemerintah No. 40 Tahun 1996 tentang Hak Guna Usaha, Hak Guna Bangunan, dan Hak Pakai atas Tanah menetapkan bahwa Hak Guna Usaha, Hak Guna Bangunan, dan Hak Pakai atas Tanah dapat beralih dan dialihkan kepada pihak lain. Dalam UUPA dan Peraturan Pemerintah No. 40 Tahun 1996 tidak memberikan pengertian apa yang dimaksud beralih dan dialihkan.

Menurut Boedi Harsono, bentuk peralihan hak atas tanah dibagi menjadi 2 (dua), yaitu: Pertama, Beralih. Beralih menunjuk pada berpindahnya hak atas tanah kepada pihak lain karena pemegang haknya meninggal dunia. Peralihan hak atas tanah ini terjadi karena hukum, artinya dengan meninggalnya pemegang hak atas tanah, maka ahli warisnya memperoleh tanah tersebut; Kedua, Dialihkan. Dialihkan menunjuk pada berpindahnya hak atas tanah kepada pihak lain karena perbuatan hukum yang sengaja dilakukan dengan tujuan agar pihak lain tersebut memperoleh hak itu. Adapun perbuatan hukum itu bisa berupa jual-beli, tukar-menukar, hibah, atau hibah wasiat atau pemberian dengan wasiat (Boedi Harsono, 1971:135).

Ruang lingkup yang lebih sempit, ada 2 bentuk peralihan hak milik atas tanah: Pertama, Beralih. Yaitu berpindahnya hak milik atas tanah dari pemiliknya kepada pihak lain karena suatu peristiwa hukum. Dengan meninggalnya pemilik tanah, maka hak milik atas tanahnya secara hukum berpindah kepada ahli warisnya yaitu sepanjang ahli warisnya memenuhi syarat sebagai subyek hak milik. Berpindahnya hak milik atas tanah dari pemiliknya kepada pihak lain melalui proses pewarisan; Kedua, Dialihkan atau pemindahan hak. Dialihkannya atau pemindahan hak artinya berpindahnya hak milik atas tanah dari pemiliknya kepada pihak lain dikarenakan adanya suatu perbuatan hukum, contoh: jual-beli, tukarmenukar, hibah, pemasukan dalam modal perusahaan, serta lelang (Urip Santoso, 2009:91-92).

Dalam kaitan dengan peralihan hak atas tanah, maka yang termasuk dalam perbuatan hukum berupa: Jual-beli; Tukar-menukar; Hibah; Pemasukan di dalam perusahaan; Pembagian hak bersama; Penggabungan atau peleburan perseroan atau koperasi yang didahului dengan likuidasi (Mhd. Yamin Lubis dan Abd. Rahim Lubis, 2008:276).
Dialihkan merupakan salah satu bentuk peralihan hak atas tanah, salah satu contoh dialihkan adalah jualbeli. Jual-beli yang dimaksudkan disini adalah jualbeli hak atas tanah. Dalam praktek disebut jual-beli tanah. Secara yuridis, yang diperjualbelikan adalah hak atas tanah bukan tanahnya. Memang benar bahwa tujuan membeli hak atas tanah adalah supaya pembeli dapat secara sah menguasai dan mempergunakan tanah. Dengan kata lain, yang menjadi obyek jualbeli disini adalah hak atas tanah. Menurut UUPA dan Peraturan Pemerintah No. 40 Tahun 1996, hak atas tanah yang menjadi obyek jual-beli adalah Hak Milik, Hak Guna Usaha, Hak Guna Bangunan, dan Hak Pakai atas Tanah. Undang-Undang No. 16 Tahun 1985 tentang Rumah Susun menetapkan bahwa hak milik atas satuan rumah susun juga menjadi obyek jual-beli.

Istilah jual-beli dalam hal pertanahan disebutkan dalam berbagai peraturan perundang-undangan, antara lain dalam Pasal 26 ayat 1 dan 2 UUPA, Penjelasan pada Pasal 10 ayat 1 Undang-Undang No. 16 Tahun 1985 tentang Rumah Susun, Pasal 16 ayat 2 huruf a, Pasal 34 ayat 2 huruf a, Pasal 54 ayat 3 huruf a Peraturan Pemerintah No. 40 Tahun 1996, Pasal 37 ayat 1 Peraturan Pemerintah No. 24 Tahun 1997 tentang Pendaftaran Tanah, Pasal 2 ayat 2 huruf a Peraturan Pemerintah No. 37 Tahun 1998 tentang Peraturan Jabatan Pejabat Pembuat Akta Tanah, Pasal 20 Peraturan Presiden No. 36 Tahun 2005 tentang Pengadaan Tanah bagi Pelaksanaan Pembangunan untuk Kepentingan Umum, dan juga Pasal 3 ayat 4 Keputusan Menteri Negara Agraria atau Kepala Badan Pertanahan Nasional No. 21 Tahun 1994 tentang Tata Cara Perolehan Tanah bagi Perusahaan dalam Rangka Penanaman Modal.

Di dalam peraturan perundang-undangan yang disebutkan di atas hanya disebutkan tentang jualbeli, tetapi tidak memberikan pengertian apa yang dimaksudkan dengan jual-beli. Untuk memahami pengertian jual-beli dapat juga dilihat dari dasar-dasar pembentukan UUPA (Hukum Agraria Nasional) yaitu didasarkan pada Hukum Adat sebagaimana disebutkan dalam Pasal 5 UUPA, yaitu dengan mengindahkan unsur-unsur yang bersandar pada hukum agama. Dengan mendasarkan pada ketentuan Pasal 5 UUPA, maka pengertian jual-beli tanah adalah jual-beli tanah menurut hukum adat, bukan jual-beli tanah menurut hukum barat.

Boedi Harsono menyatakan bahwa pengertian jual-beli tanah adalah perbuatan hukum yang berupa penyerahan atas hak milik (penyerahan tanah untuk selama-lamanya) oleh penjual kepada pembeli, yang 
pada saat itu juga menyerahkan harganya kepada penjual. Jual-beli yang mengakibatkan beralihnya hak milik atas tanah dari penjual kepada pembeli itu termasuk dalam Hukum Agraria atau Hukum Tanah (Boedi Harsono, 1971:135). Pengertian jual-beli tanah dalam pengertian ini obyeknya hanya terbatas pada tanah hak milik. Dalam hukum positif, obyek jualbeli tanah tidak hanya Hak Milik, namun juga Hak Guna Usaha, Hak Guna Bangunan, Hak Pakai, dan Hak Milik atas Satuan Rumah Susun.

Jual-beli tanah adalah suatu perbuatan hukum berupa penyerahan hak atas tanah untuk selamalamanya dari pemilik atau pemegang hak atas tanah sebagai penjual kepada pihak lain sebagai pembeli, yang pada saat itu diserahkan sejumlah uang sebagai harga oleh pembeli kepada penjual. Dengan jualbeli ini, hak atas tanah berpindah dari pemilik atau pemegang hak atas tanah sebagai penjual kepada pembeli.

Dalam hukum adat tentang tanah dikenal 3 (tiga) macam jual atau adol, yaitu: Pertama, Jual lepas atau adol plas. Pada jual lepas atau adol plas, pemilik tanah menyerahkan tanahnya untuk selama-lamanya kepada pihak lain (pembeli) dengan sejumlah uang yang besarnya ditentukan atas dasar kesepakatan antara pemilik tanah dengan pihak lain (pembeli); Kedua, Jual gadai atau adol gadai. Pada jual gadai atau adol gadai, pemilik tanah pertanian (pemberi gadai) menyerahkan tanahnya untuk digarap kepada pihak lain (pemegang gadai) yaitu dengan menerima sejumlah uang dari pihak lain (pemegang gadai) sebagai uang gadai dan tanah dapat kembali kepada pemiliknya apabila pemilik tanah menebus uang gadai; Ketiga, Jual tahunan dan atau adol tahunan. Pada jual tahunan atau adol tahunan, pemilik tanah pertanian menyerahkan tanahnya untuk digarap dalam beberapa kali masa panen kepada pihak lain (pembeli) dengan pembayaran sejumlah uang yang besarnya ditentukan atas dasar kesepakatan antara pemilik tanah dengan pembeli. Setelah beberapa kali masa panen sesuai kesepakatan kedua belah pihak, tanah pertanian diserahkan kembali oleh pembeli kepada pemilik tanah (Urip Santoso, 2010:359-360).

Effendi Perangin menyatakan bahwa sifat-sifat jual-beli tanah menurut hukum adat, yaitu: Pertama, Contant atau tunai. Contant atau tunai, artinya harga tanah yang dibayar itu bisa seluruhnya, tetapi bisa juga sebagian. Tetapi biarpun dibayar sebagian, menurut hukum dianggap telah dibayar penuh. Pembayaran harga dan penyerahan haknya dilakukan pada saat yang bersamaan. Pada saat itu, jual-beli menurut hukum telah selesai. Sisa harga yang belum dibayar dianggap sebagai suatu utang pembeli kepada bekas pemilik tanah (penjual). Ini berarti, jika kemudian pembeli tidak membayar sisa harganya, maka bekas pemilik tanah tidak dapat membatalkan jual-beli tanah tersebut. Penyelesaian pembayaran sisa harga tersebut dilakukan menurut hukum perjanjian utang piutang. Kedua, Terang. Terang yaitu artinya jual-beli tanah tersebut dilakukan dihadapan Kepala Desa atau Kepala Adat yang tidak hanya bertindak sebagai saksi, tetapi juga dalam kedudukannya sebagai pihak yang bertanggungjawab bahwa jual-beli tanah tersebut tidak melanggar hukum yang berlaku. Jual-beli tanah yang dilakukan dihadapan Kepala Desa atau Kepala Adat ini menjadi terang, bukan perbuatan hukum yang gelap, artinya pembeli mendapatkan pengakuan dari masyarakat yang bersangkutan sebagai pemilik tanah yang baru dan mendapatkan perlindungan hukum jika di kemudian hari ada gugatan terhadapnya dari pihak yang menganggap jual-beli tanah tersebut tidak sah (Effendi Perangin, 1989:16).

Sependapat dengan Effendi Perangin, Maria S.W. Sumardjono menyatakan bahwa sifat jual-beli tanah menurut hukum adat adalah: Tunai. Tunai artinya penyerahan hak-hak atas tanah oleh pemilik tanah (penjual) dilakukan bersamaan dengan pembayaran harganya oleh pihak lain (pembeli). Dengan perbuatan hukum jual-beli tersebut, maka seketika itu juga terjadi peralihan hak atas tanah. Harga yang dibayar pada saat penyerahan hak tidak harus lunas atau penuh dan hal ini tidak mengurangi sifat tunai tadi. Kalau terdapat selisih atau sisa dari harga, maka hal ini dianggap utang pembeli kepada penjual yang tunduk pada hukum utang-piutang; Riil. Riil artinya kehendak atau niat yang diucapkan harus diikuti dengan perbuatan yang nyata menunjukkan tujuan jual-beli tersebut, misalnya diterimanya uang oleh penjual, dan dibuatnya perjanjian di hadapan Kepala Desa; Terang. Terang artinya untuk perbuatan hukum tersebut haruslah dilakukan dihadapan Kepala Desa sebagai tanda bahwa perbuatan itu tidak melanggar ketentuan dalam hukum yang berlaku (Maria S.W. Sumardjono, 1993:11).

Menurut hukum adat, jual-beli tanah adalah suatu perbuatan pemindahan hak atas tanah yang bersifat terang dan tunai. Terang berarti perbuatan pemindahan hak tersebut harus dilakukan dihadapan kepala adat, yang berperan sebagai pejabat yang menanggung keteraturan dan sahnya perbuatan pemindahan hak tersebut, sehingga suatu perbuatan tersebut diketahui oleh umum. Tunai maksudnya, bahwa perbuatan pemindahan hak dan pembayaran harganya dilakukan secara serentak. Oleh karena itu, mungkin berarti 
harga tanah dibayar secara kontan atau baru dibayar sebagian. Dalam hal pembeli membayar sisanya, maka penjual tidak dapat menuntut atas dasar terjadinya jual-beli tanah, akan tetapi atas dasar hukum utangpiutang (Andrian Sutedi, 2007:72).

Syarat sah jual-beli tanah menurut hukum adat adalah pihak penjual dan pembeli harus memenuhi suatu syarat materiil sebagai subyek dari tanah yang diperjualbelikan, dan syarat formalnya adalah jualbeli tanah tersebut dilakukan dihadapan Kepala Desa atau Kepala Adat dimana tanah yang diperjualbelikan tersebut terletak.

Sebagai perbandingan, berikut ini dapat diuraikan tentang jual-beli tanah menurut Burgerlijk Wetboek (yang selanjutnya disebut BW). Adapun pengertian jual-beli disebutkan dalam Pasal 1457 BW, yaitu suatu persetujuan pihak yang satu mengikatkan dirinya untuk menyerahkan suatu kebendaan, dan pihak yang lain untuk membayar harga yang telah diperjanjikan. Selanjutnya, dalam Pasal 1458 BW dinyatakan bahwa jual-beli dianggap telah terjadi antara kedua belah pihak, seketika setelahnya orang-orang ini mencapai sepakat tentang kebendaan tersebut dan harganya, meskipun kebendaan itu belum diserahkan maupun harganya belum dibayar.

Khusus jual-beli tanah pada masa berlakunya Hukum Agraria Kolonial diatur dalam Overschrijving Ordonnantie Stb. 1934 No. 27, yang dapat dinyatakan bahwa jual-beli tanah terdapat 2 (dua) perbuatan hukum, yaitu: Pertama, Perjanjian jual-beli tanah dibuat dengan akta notaris dan atau akta di bawah tangan. Perjanjian jual-beli tanah ini pengaturannya termasuk hukum perjanjian. Pada saat ini belum terjadi pemindahan hak atas tanah dari penjual kepada pembeli. Kedua, Penyerahan yuridis atau juridische levering dapat diselenggarakan dengan pembuatan akta balik nama di muka dan oleh Kepala Kantor Pendaftaran Tanah selaku Overschrijving Ambtenaar. Pada saat inilah terjadi pemindahan hak atas tanah dari penjual kepada pembeli (Urip Santoso, 2010:362).

Jual-beli tanah menurut hukum adat terdapat satu perbuatan hukum yaitu hak atas tanah berpindah dari penjual kepada pembeli pada saat dibayarnya harga tanah secara tunai atau contant oleh pembeli kepada penjual. Adapun jual-beli tanah menurut aturan hukum adat bukanlah merupakan perjanjian sebagaimana yang ditegaskan dalam Pasal 1457 BW, melainkan suatu perbuatan hukum yang dimaksudkan untuk memindahkan hak atas tanah dari pemegang hak sebagai penjual kepada pihak lain sebagai pembeli dengan pembayaran sejumlah uang secara tunai atau contant dan dilakukan secara terang.
Syarat sahnya suatu jual-beli tanah hak milik bagi penjual dan pembeli ada 2 (dua), yaitu: Pertama, Syarat materiil. Pemilik tanah sebagai penjual berhak dan berwenang menjual tanah miliknya, sedangkan pembeli memenuhi syarat sebagai subyek hak milik yang menjadi obyek jual-beli. Syarat materiil bagi pemilik tanah sebagai penjual, yaitu: orang yang berhak menjual tanah yaitu orang yang namanya tercantum dalam tanda bukti hak milik, yaitu dalam Sertipikat atau Petuk Pajak Bumi atau Landrente, Girik, Pipil, Kekitir, Verponding Indonesia, atau juga Kutipan Letter C; seseorang berwenang menjual tanahnya adalah orang yang sudah dewasa dalam melakukan suatu perbuatan hukum; kalau penjualnya belum dewasa, maka ia diwakili oleh walinya; kalau penjualnya dalam pengampuan, maka ia diwakili oleh pengampunya; kalau penjualnya diwakili oleh orang lain sebagai penerima kuasa, maka penerima kuasa harus sudah dewasa untuk melakukan suatu perbuatan hukum dan akta kuasanya dibuat secara notariil; kalau tanah hak milik yang mau dijual merupakan harta bersama, maka penjualnya harus mendapatkan persetujuan terlebih dahulu dari suami atau istri. Syarat materiil bagi pembeli, yaitu pembeli harus memenuhi syarat sebagai subyek hak milik atas tanah yang menjadi obyek jual-beli. Subyek hak milik atas tanah adalah Warga Negara Indonesia.

Kedua, Syarat formal. Syarat formal dalam jualbeli tanah berkaitan dengan pembuktian terjadinya jual-beli tanah. Untuk suatu kepentingan pendaftaran jual-beli tanah kepada Kantor Pertanahan Kabupaten atau Kota setempat, maka jual-beli tanah hak milik yang telah bersertipikat maupun selain sertipikat harus dibuktikan dengan adanya akta yang dibuat oleh dan dihadapan Pejabat Pembuat Akta Tanah (yang selanjutnya disebut PPAT) sesuai dengan ketetapan dalam Pasal 37 ayat 1 Peraturan Pemerintah No. 24 Tahun 1997. Namun ketentuan ini tidak absolut, karena syarat-syarat formal dalam jual-beli tanah hak milik tidak mutlak harus dibuktikan dengan akta PPAT, karena dalam keadaan tertentu sebagaimana ditentukan oleh Kepala BPN RI dan Kepala Kantor Pertanahan Kabupaten atau Kota dapat mendaftar pemindahan hak melalui jual-beli atas bidang tanah hak milik yang para pihaknya Warga Negara Indonesia yang dibuktikan dengan akta yang tidak dibuat oleh PPAT, tetapi kebenarannya dianggap cukup untuk mendaftar pemindahan hak yang bersangkutan. Hal ini sesuai yang ditegaskan dalam Pasal 37 ayat 2 Peraturan Pemerintah No. 24 Tahun 1997.

Syarat materiil dalam jual-beli tanah mempunyai kaitan erat dengan syarat formalnya. Syarat materiil 
menentukan dapat dipenuhinya syarat formal. Kalau syarat materiil tidak dapat dipenuhi oleh pihak penjual dan pembeli, maka syarat formalnya tidak akan dapat dipenuhi. Kalau syarat materiil dalam jual-beli tanah tidak dapat dipenuhi oleh penjual dan pembeli, maka PPAT tidak akan membuatkan akta jual-beli tanah.

Dalam rangka pembuktian adanya jual-beli tanah hak milik dan untuk kepentingan pendaftaran jual-beli tanah hak milik, jual-beli tanah hak milik dibuktikan dengan akta yang dibuat oleh dan dihadapan PPAT. Ketentuan ini ditetapkan di dalam Pasal 37 ayat 1 Peraturan Pemerintah No. 24 Tahun 1997. PPAT berwenang membuat akta jual-beli hak atas tanah di atur dalam Pasal 3 Peraturan Pemerintah No. 37 Tahun 1998 tentang Peraturan Jabatan Pejabat Pembuat Akta Tanah. Disamping jual-beli, perbuatan hukum mengenai hak atas tanah yang kewenangan pembuatan aktanya dapat diserahkan kepada PPAT adalah tukarmenukar, hibah, pemasukan ke dalam perusahaan atau inbreng, pembagian hak bersama, pemberian Hak Guna Bangunan atau Hak Pakai atas tanah hak milik, pemberian Hak Tanggungan, dan pemberian kuasa membebankan Hak Tanggungan.

Dengan telah dibuatnya akta jual-beli tanah hak milik oleh PPAT, maka pada saat itu telah terjadi pemindahan hak milik dari pemilik tanah sebagai penjual kepada pihak lain sebagai pembeli. Namun, pemindahan hak milik atas tanah tersebut hanya diketahui oleh penjual dan pembeli, pihak ketiga tidak mengetahui adanya jual-beli tanah hak milik tersebut. Agar pihak ketiga mengetahui adanya jualbeli tanah hak milik tersebut, maka pihak pembeli mempunyai kewajiban administratif terhadap tanah yang dibelinya yaitu mendaftarkan jual-beli tanah hak milik tersebut kepada Kepala Kantor Pertanahan Kabupaten atau Kota yang wilayah kerjanya meliputi letak tanah yang bersangkutan. Maksud pendaftaran pemindahan hak adalah Kepala Kantor Pertanahan Kabupaten atau Kota yang wilayah kerjanya meliputi letak tanah yang bersangkutan melakukan perubahan nama pemilik tanah dalam sertipikat dari atas nama penjual menjadi atas nama pembeli.

Dalam realita terdapat tanah hak milik yang telah terdaftar yaitu tanah hak milik yang telah diterbitkan sertipikat hak atas milik oleh Kantor Pertanahan Kabupaten atau Kota. Ada pula tanah hak milik yang belum terdaftar atau belum bersertipikat, yaitu tanah hak hilik yang bertanda bukti Petuk Pajak Bumi atau Landrente, Girik, Kekitir, Pipil, IPEDA, IREDA, atau Kutipan Letter C. Tanah hak milik yang bertanda bukti selain sertipikat disebut tanah yasan atau tanah bekas milik adat.
Pemilik tanah yasan atau tanah bekas milik adat mempunyai hak untuk memindahkan tanah miliknya kepada pihak lain melalui jual-beli. Pemindahan hak tanah hak milik melalui jual-beli ini mempunyai perbedaan mekanisme jual-belinya dengan bergantung kepada kepentingannya, yaitu: Pertama, Jual-beli tanah hak milik yang tidak ingin didaftarkan pada Kantor Pertanahan Kabupaten atau Kota. Penjual dan pembeli harus memenuhi syarat materiil dalam jual-beli tanah hak milik, yaitu penjual berhak dan berwenang untuk menjual tanah miliknya, sedangkan pembeli memenuhi syarat sebagai subyek hak milik yang menjadi obyek jual-beli. Jual-beli tanah hak milik ini tidak harus dibuat dengan akta PPAT. Dalam praktek, jual-belinya dibuat dengan akta di bawah tangan yaitu jual-belinya dibuat oleh penjual dan pembeli sendiri yang diketahui oleh Kepala Desa atau Kepala Kelurahan, atau dibuatkan oleh Kepala Desa atau Kepala Kelurahan setempat.

Dalam jual-beli tanah hak milik ini penjual dapat menyerahkan kepada Kepala Desa dan atau Kepala Kelurahan, yaitu berupa: 1. Petuk Pajak Bumi atau Landrente, Girik, Kekitir, Pipil, Verponding Indonesia, atau Kutipan Letter $\mathrm{C}$ tanah yang diperjualbelikan; 2 . Riwayat tanah yang diperjualbelikan; 3. Surat Pemberitahuan Pajak Terhutang Pajak Bumi dan Bangunan (SPPT PBB) tanah yang akan diperjualbelikan; 4. Fotokopi Kartu Tanda Penduduk (KTP) penjual yang masih berlaku; 5. Fotokopi Kartu Tanda Penduduk (KTP) suami atau istri penjual apabila tanah yang diperjualbelikan tersebut merupakan harta bersama. Dalam jual-beli tanah hak milik ini, pembeli hanya menyerahkan fotokopi Kartu Tanda Penduduk (KTP) yang masih berlaku kepada Kepala Desa atau Kepala Kelurahan.

Jual-beli tanah hak milik dapat ditandatangani oleh penjual, pembeli, 2 (dua) orang saksi, Kepala Desa atau Kepala Kelurahan, dan suami atau istri apabila tanah yang diperjualbelikan merupakan harta bersama. Setelah jual-beli tanah hak milik tersebut ditandatangani oleh penjual dan pembeli, Kepala Desa atau Kepala Kelurahan mencatat jual-beli tanah tersebut pada Petuk Pajak Bumi atau Landrente, Girik, Kekitir, Pipil, Verponding Indonesia atau juga Kutipan Letter C pada Buku Administrasi Tanah yang bersangkutan. Kemudian Kepala Desa atau Kepala Kelurahan menerbitkan Kutipan Letter C yang baru sebagai pengganti Petuk Pajak Bumi atau Landrente, Girik, Kekitir, Pipil, Verponding Indonesia, atau Kutipan Letter C yang lama.

Kedua, Jual-beli tanah atas hak milik yang ingin didaftarkan di Kantor Pertanahan Kabupaten atau 
Kota. Penjual dan pembeli harus memenuhi syarat materiil dalam jual-beli tanah hak milik, yaitu penjual berhak dan berwenang pula menjual tanah miliknya, sedangkan pembeli memenuhi syarat sebagai subyek hak milik yang menjadi obyek jual-beli.

Jual-beli tanah hak milik ini harus dibuat dengan akta PPAT. Kalau jual-belinya dibuat dengan akta di bawah tangan, yaitu jual-belinya dapat dibuat oleh penjual dan pembeli sendiri yang diketahui oleh Kepala Desa atau Kepala Kelurahan, atau dibuatkan oleh Kepala Desa atau Kepala Kelurahan setempat, maka pendaftaran jual-beli tanah hak milik ke Kantor Pertanahan Kabupaten atau Kota akan ditolak. Kalau jual-beli tanah hak milik ingin dapat didaftar oleh Kepala Kantor Pertanahan Kabupaten atau Kota, maka harus dibuat jual-beli ulang oleh penjual dan pembeli yang dibuktikan dengan akta PPAT. Ketentuan yang menunjukkan bahwa jual-beli tanah hak milik ini harus dibuktikan dengan akta PPAT, adalah Pasal 37 ayat 1 dan Pasal 39 ayat 1 huruf b Peraturan Pemerintah No. 24 Tahun 1997.

Di dalam jual-beli tanah hak milik ini, penjual menyerahkan kepada PPAT, berupa: Petuk Pajak Bumi atau Landrente, Girik, Kekitir, Pipil, Verponding Indonesia, atau Kutipan Letter $\mathrm{C}$ tanah yang diperjualbelikan; Riwayat tanah yang diperjualbelikan; Surat Pemberitahuan Pajak Terhutang Pajak Bumi dan Bangunan (SPPT PBB) tanah yang diperjualbelikan; Kartu Tanda Penduduk (KTP) penjual yang masih berlaku; Kartu Tanda Penduduk (KTP) suami atau istri penjual apabila tanah yang diperjual-belikan tersebut merupakan harta bersama. Dalam jual-beli tanah hak milik ini, pembeli hanya menyerahkan fotokopi Kartu Tanda Penduduk (KTP) yang masih berlaku kepada PPAT.

Dalam jual-beli tanah hak milik ditandatangani oleh penjual, pembeli, 2 (dua) orang saksi, Kepala Desa atau Lurah berkedudukan sebagai saksi, dan juga suami atau istri apabila tanah yang diperjualbelikan merupakan harta bersama. Setelah akta jual-beli tanah hak milik ditandatangani oleh penjual dan pembeli, maka tanah hak milik tersebut telah berpindah dari penjual kepada pembeli. Dalam jual-beli tanah hak milik ini Kepala atau Desa Lurah mencatat jualbeli tanah tersebut pada Petuk Pajak Bumi atau pun Landrente, Girik, Kekitir, Pipil, Verponding Indonesia atau Kutipan Letter $C$ pada buku administrasi tanah yang bersangkutan. Kemudian Kepala Desa atau pun Kepala Kelurahan menerbitkan Kutipan Letter C yang baru sebagai pengganti Petuk Pajak Bumi atau Landrente, Girik, Kekitir, Pipil, Verponding Indonesia, atau Kutipan Letter C yang lama.
Maksud jual-beli tanah hak milik ini didaftarkan ke Kantor Pertanahan Kabupaten atau Kota oleh pihak pembeli tanah, adalah pembeli tanah hak milik bermaksud mensertipikatkan atau mendaftarkan tanah yang dibelinya kepada Kepala Kantor Pertanahan Kabupaten atau Kota setempat.

\section{PENUTUP \\ Kesimpulan}

Tanah hak milik dapat beralih dan dapat dialihkan kepada pihak lain. Beralih artinya tanah hak milik berpindah dari pemiliknya kepada pihak lain melalui proses pewarisan, sedangkan dialihkan artinya tanah hak milik berpindah dari pemiliknya kepada pihak lain karena suatu perbuatan hukum. Salah satu contoh perbuatan hukum adalah jual-beli.

Jual-beli tanah hak milik dapat terjadi apabila memenuhi syarat sahnya yaitu syarat materiil dan syarat formal. Syarat materiil dalam jual-beli tanah adalah penjual berhak dan berwenang menjual tanah hak miliknya, sedangkan pembeli harus memenuhi syarat sebagai subyek hak milik yang menjadi obyek jual-beli. Syarat formal dalam jual-beli tanah adalah berkaitan dengan pembuktian dalam jual-beli tanah.

Kalau jual-beli tanah hak milik dimaksudkan untuk didaftarkan oleh pembelinya ke Kantor Pertanahan Kabupaten atau Kota, maka jual-beli tanah hak milik tersebut tidak cukup dibuat dengan akta di bawah tangan yang diketahui oleh Kepala Desa atau Kepala Kelurahan, akan tetapi proses jual-beli tanahnya harus dibuktikan dengan akta PPAT.

\section{Rekomendasi}

Kantor Pertanahan Kabupaten atau Kota dalam melakukan pendaftaran harus memperhatikan syarat formal untuk membuktikan adanya jual-beli tanah, yaitu dengan Akta PPAT.

\section{DAFTAR PUSTAKA \\ Buku:}

Harsono, Boedi, 1971, Undang-Undang Pokok Agraria Sedjarah Penjusunan, Isi, dan Pelaksanaannja, Djakarta: Djambatan.

Lubis, Mhd. Yamin, dan Abd. Rahim Lubis, 2008, Hukum Pendaftaran Tanah, Bandung: Mandar Maju.

Perangin, Effendi, 1989, Hukum Agraria Indonesia Suatu Telaah dari Sudut Pandang Praktisi Hukum, Jakarta: Rajawali.

Santoso, Urip, 2009, Hukum Agraria dan Hak-hak atas Tanah, Jakarta: Prenada Media. ,2010, Pendaftaran dan Peralihan Hak atas 
Tanah, Jakarta: Prenada Media.

Sumardjono, Maria S.W., 1993, "Aspek Teoritis

Peralihan Hak atas Tanah Menurut UUPA", Majalah MIMBAR HUKUM, No. 18/X/93, Fakultas Hukum Universitas Gadjah Mada, Yogyakarta. , 2008, Tanah dalam Perspektif Hak Ekonomi Sosial dan Budaya, Jakarta: Kompas.

Supriadi, 2007, Hukum Agraria, Jakarta: Sinar Grafika.

Sutedi, Adrian, 2007, Peralihan Hak atas Tanah dan Pendaftarannya, Jakarta: Sinar Grafika.

\section{Peraturan Perundang-undangan:}

Undang-Undang No. 5 Tahun 1960 tentang Peraturan Dasar Pokok-pokok Agraria.
Undang-Undang No. 16 Tahun 1985 tentang Rumah Susun.

Peraturan Pemerintah No. 40 Tahun 1996 tentang Hak Guna Usaha, Hak Guna Bangunan, dan Hak Pakai atas Tanah.

Peraturan Pemerintah No. 24 Tahun 1997 tentang Pendaftaran Tanah.

Peraturan Pemerintah No. 37 Tahun 1998 tentang Peraturan Jabatan Pejabat Pembuat Akta Tanah. Peraturan Presiden No. 36 Tahun 2005 tentang Pengadaan Tanah bagi Pelaksanaan Pembangunan untuk Kepentingan Umum.

Keputusan Menteri Negara Agraria/Kepala Badan Pertanahan Nasional No. 21 Tahun 1994 tentang Tata Cara Perolehan Tanah bagi Perusahaan Dalam Rangka Penanaman Modal. 